\title{
Detecting land use and climate impacts on water yield ecosystem service in arid and semi-arid areas. A study in Sirvan River Basin-Iran
}

\author{
Jahanbakhsh Balist ${ }^{1} \cdot$ Bahram Malekmohammadi $^{1} \cdot$ Hamid Reza Jafari $^{1} \cdot$ Ahmad Nohegar $^{1} \cdot$ Davide Geneletti $^{2}$
}

Received: 22 August 2021 / Accepted: 16 November 2021 / Published online: 29 November 2021

(c) The Author(s) 2021

\begin{abstract}
This study investigates how land use and climate changes affect water yield ecosystem service (ES) in the Sirvan River basin, located in Iran's Kurdistan and Kermanshah provinces. By detecting land-use and climatic parameter changes in the past, their future evolution were modeled by scenario making. For this purpose, we developed two land-use scenarios (low and high urbanization) and two climatic scenarios (Representative Concentration Pathway 2.6 and RCP 8.5). The implemented scenarios showed how the amount of water yield in the basin and sub-basins changes in the future based on climate and land-use changes. The results showed that, concerning land use, the forest has decreased from 2013 to 2019, and built-up areas have increased. Also, the results showed that precipitation has been declining in the long term, and the temperature has been rising. Finally, the Water yield in 2019 was higher than in 2013 and lower in the future based on forecast scenarios. This trend will continue until 2040. In addition, it was found that the $t$ effects of these factors on water yield ES are a complex process, and based on the results, the impact of climatic factors is more significant than the one of land-use change. We could conclude that this region will face more environmental problems in the future.
\end{abstract}

Keywords Ecosystem services $\cdot$ Water yield $\cdot$ Climate change $\cdot$ Land-use $\cdot$ Scenario-making $\cdot$ Sirvan river basin

\begin{tabular}{|c|c|}
\hline \multicolumn{2}{|c|}{ Abbreviations } \\
\hline ES & Ecosystem services \\
\hline LU/LC & Land use land cover \\
\hline InVEST & $\begin{array}{l}\text { Integrated valuation of ecosystem services and } \\
\text { trade-offs }\end{array}$ \\
\hline $\mathrm{RCP}$ & Representative concentration pathway \\
\hline IPCC & Intergovernmental panel on climate change \\
\hline GCMs & General circulation models \\
\hline CIMP5 & Coupled model intercomparison project phase 5 \\
\hline ENVI & Environment for visualizing images \\
\hline LUMC & Low urbanization and moderate climate \\
\hline LUSC & Low urbanization and severe climate \\
\hline HUMC & High urbanization and moderate climate \\
\hline HUSC & High urbanization and severe climate \\
\hline
\end{tabular}

Bahram Malekmohammadi malekb@ut.ac.ir

1 School of Environment, College of Engineering, University of Tehran, Tehran, Iran

2 Department of Civil, Environmental and Mechanical Engineering, University of Trento, Via Mesiano 77, 38123 Trento, Italy

\section{Introduction}

Over the last decade, the ecosystem service (ES) approach was in the spotlight because it presents significant advantages for enhancing environmental planning and decisionmaking processes (Rozas-Vásquez et al. 2019). Integrating ES concepts into decision-making is possible if aspects such as common understanding of ES among the stakeholders, information availability, and official guidelines are considered (Atumane and Cabral. 2021). The integration of ES into planning has mainly been debated at a theoretical level (Hansen and Pauleit 2014), while there is less evidence on the efforts proposing the integration of ES into decisions about land use (Ashnani et al. 2018). The number of ES assessments has increased in the last decade, as shown by recent studies at supranational (Maes et al. 2020), national (Mugiraneza et al. 2019) and regional levels (Nikodinoska et al. 2018). Still, there are difficulties in defining and operationalizing ES within planning due to, among other things, rigid regulatory frameworks and inadequate tools ( $\mathrm{Di}$ Marino et al. 2019).

Many factors influence ES, most importantly, land use (Lang et al. 2017) and climate change. Land use patterns can directly change ecosystem types, landscape patterns, and 
ecological processes, thus affecting ES, such as biodiversity, river basin, and water yield (Lang et al. 2017). The rapid change in land use, associate with growing climate change, has dramatically influenced ecosystem structure and services (Lang et al. 2017). LULC changes can alter hydrologic cycles, shifting patterns of evapotranspiration, infiltration and water retention, and changing the timing and volume of available water (World Commission on Dams 2000). Recent researches have shown that human-made changes in land use and land cover such as deforestation, cultivated land expansion, and urbanization have irreversible impacts on ES (Bounoua et al. 2018; Li et al. 2019; Aliani et al. 2019).

Several studies have already revealed that human activities can cause changes in the hydrological response of catchments (Rather et al. 2020; Tahiru et al. 2020). As well as climate change/variability can affect precipitation, runoff, and flood frequency (Afzal and Ragab 2020; Torabi Haghighi et al. 2020). Water yield is one of the most vital services provided by ecosystems and is of great significance to the sustainable development of the regional economy and ecosystem. Water yield can meet human irrigation, production, and domestic water and has entertainment and aesthetic value. It also affects ecological functions such as biomass, carbon cycle, and sediment output (Yang et al. 2021). As an essential ES, water regulation is affected by the combined effects of land use and climate change (Sun et al. 2015). Climate change can influence water yield by changing the temperature and precipitation in a catchment (Lang et al. 2017). Land-use changes can also affect water yield by altering the underlying surface of the river basin (Song and Deng 2017).

To evaluate the impact of land use and land cover changes on the basin's hydrology, spatially dispersed hydrological models are employed. The Soil and Water Assessment Tool (SWAT) model (Munoth and Goyal 2020), Integrated Valuation of Ecosystem Services and Tradeoffs (InVEST) models (Zhao et al. 2019) and Artificial Intelligence for Ecosystem Services (ARIES) model (Bagstad et al. 2015) are some of the most popular approaches used to evaluate water supply services. The InVEST model has been widely used in ES function assessment, especially in water supply assessment. Its advantages are fewer model parameters, lower data requirements, and global application (Yang et al. 2021).

Changes in climatic parameter distributions, including extremes, are critically crucial for analyzing land-use systems that incorporate complex, nonlinear interactions at the soil-plant-atmosphere interface (Vesely et al. 2019). To develop climate scenarios, multi-model aggregates of General Circulation Models (GCMs) are used, which specify the uncertainty in projections outcoming from structural differences in the GCMs and uncertainties in variations of initial conditions or parameterizations (Pachauri et al. 2014). Future projections are made according to alternative Representative Concentration Pathways (RCPs); each of them explains a potential future greenhouse gas concentration trajectory during the twenty-first century (Vesely et al. 2019). However, using climate predictions from GCMs is problematic because their coarse spatial resolution may result in biases and uncertainties at a local scale, since GCMs used to project future climate scenarios provide gridded-area average simulations. At the same time, the occurrence and intensity of extreme events strongly depend on local factors (Ragno et al. 2018; Vesely et al. 2019). Furthermore, GCM models run at a large spatial resolution (in the range of 100-300 km) require the outputs of these models to be downscaled for local studies. Downscaling methods are categorized into two methods: statistical and dynamic (Xu and Yang 2012). One of the general methods is the change factor that has been used frequently in recent research (Anandhi et al. 2001). More sophisticated methods are the SDSM (Wilby et al. 2002) and LARS-WG, among the statistical methods (Chen et al. 2011).

The current status does not describe the favorable conditions for water resources in the Middle East; In addition, the projected changes in hydro-climatic variables reinforce the struggle to manage the region's water resources in the future. Climate change projections suggest that the Middle East will face a 5-25\% decrease in annual precipitation. In Iran, for example, this annual decrease in precipitation is expected to be $20-25 \%$ of the current value (Mansouri Daneshvar et al. 2019). In addition, anthropogenic activities may also make the situation more challenging for managing water resources. It is estimated, for instance, that groundwater resources depletion is occurring in Iran with a mass loss rate of $25 \pm 3 \mathrm{~km}^{3} /$ year (Bozorg-Haddad et al. 2020). Also, land use studies in parts of the Zagros region, including Arasbaran (Rezaee Moghadam et al. 2010), Bane (Amini et al. 2009), Ilam dam catchment (Shahkooeei et al. 2014), Saman forests, Chaharzebar forests (Khan Hasani et al. 2008), (Susani et al. 2010), Ilam province forests (Mahdavi, 2010), Marivan forests (Yusefi et al. 2012), and Kurdistan region demonstrate remarkable degradation in these region land use patterns. Therefore, an assessment of water scarcity is required to quantify the availability of regional water sources and their possible changes due to climate change and assess the current and future water uses needed to maintain economic and environmental quality (Bozorg-Haddad et al. 2020).

Sirvan Basin is a mid-size basin in the Zagros Mountain region, and, as a sub-basin of Tigris, it represents a strategic water supply ecosystem. The water yield of Sirvan plays a vital role in supporting the environmental aspects of Iran and Iraq. However, climate change and human activities have become more and more intense in recent decades. The continuous expansion of agricultural areas and economic development have led to the deterioration of vegetation and water shortages in this basin, which could 
lead to intensifying social and ecological tensions. Therefore, it is essential to analyze the relationships between climate change, land-use change, and water supply services and clarify the drivers of water yield changes to ensure sustainable water supply in the Sirvan Basin. No previous study has analyzed water supply services and the impact of climate and land-use change on water yield in the Sirvan Basin simultaneously. We analyzed the change in water supply services due to climate and land-use change by: (i) Describing land-use changes; (ii) Forecasting future climate change by LARS-WG, (iii) estimating water yield using the InVEST model, and (iv) Exploring the effects of precipitation, evapotranspiration, and land-use change on water yield under different scenarios. This study can present reference information for water resource management and ecological protection in the Sirvan Basin and similar ecosystems.

\section{Materials and methods}

\section{Study area}

Sirvan Basin is a transboundary upstream catchment of a large Tigris basin located in the west of Iran, Kurdistan. Its headwaters originate in the Zagros Mountains in western Iran, and it consists of 11 sub-basins. The basin is situated between 33.2168 and $35.8338 \mathrm{~N}$ and between 44.5008 and 46.8338E (Al-Faraj and Scholz 2015). The basin drains a $32,600 \mathrm{~km}^{2}$ area, of which about $43 \%$ lies in Iraq and $57 \%$ in Iran (Ministry of Water Resources, 1982). This study was conducted on 11 sub-basins of this basin with $13,407 \mathrm{~km}^{2}$. (Fig. 1).

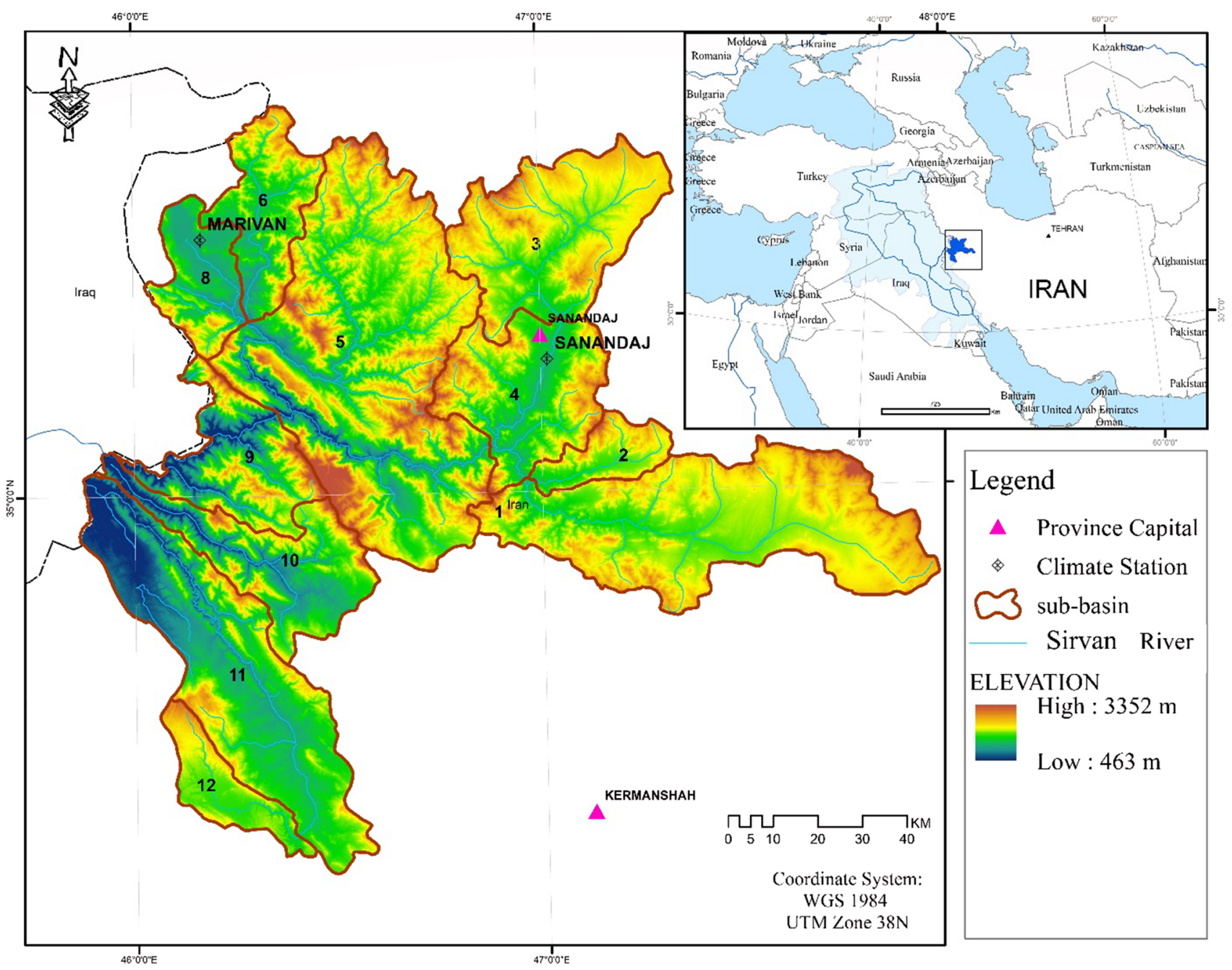

Fig. 1 Location of the study area 


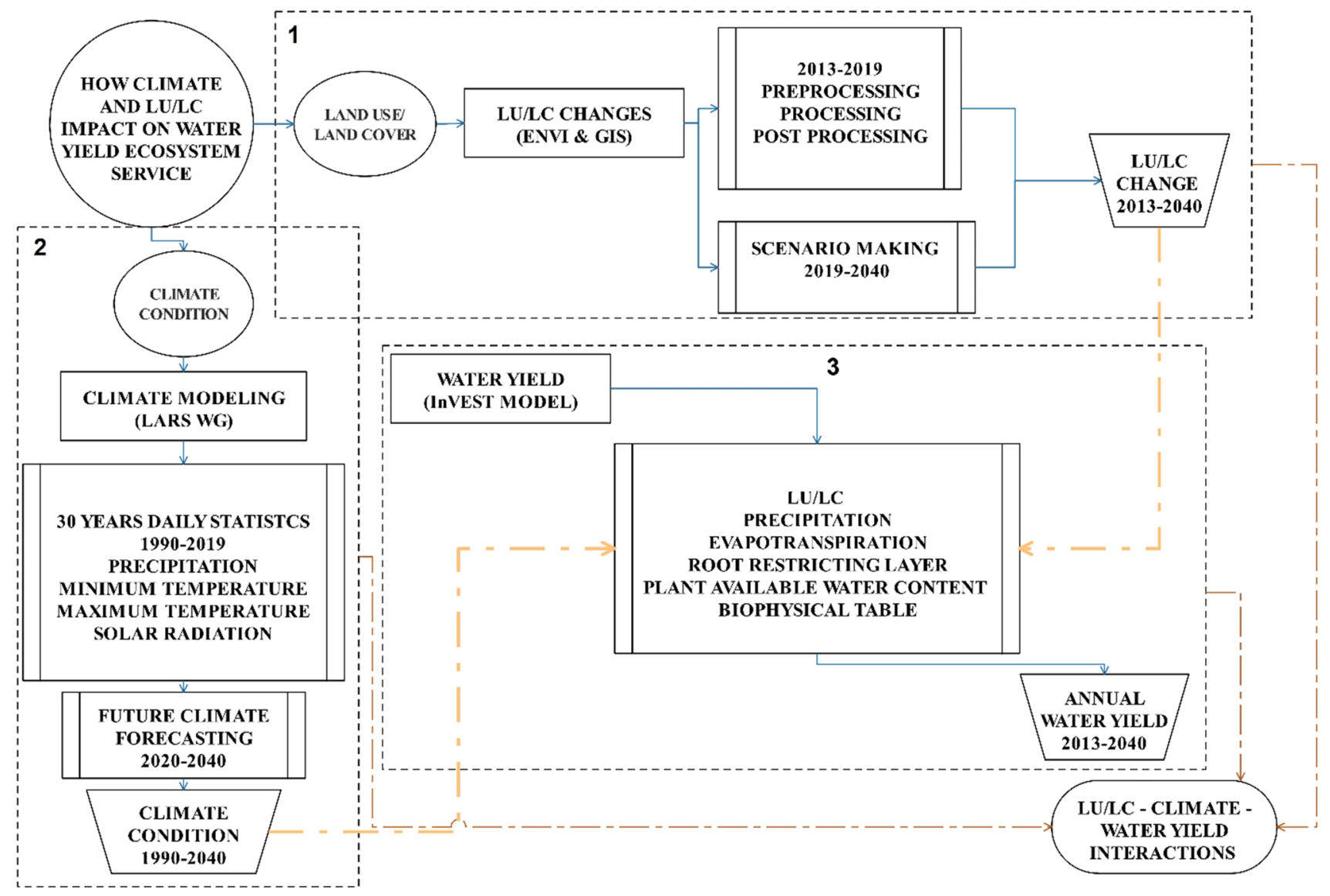

Fig. 2 Flowchart of the study

\section{Methodology}

The research follows the flowchart represented in Fig. 2. As shown, the first step is land-use change modeling in the past two decades and climate change modeling in the three past decades. Next, the past changes are used to train models for future prediction. Then, these outcomes are used to generate future land-use scenarios. Finally, the scenarios are used to model water yield in the study area. The methods and models adopted in the different steps are detailed in the following sub-sections.

\section{Climate parameters modeling}

The LARS-WG model is a random generator for producing meteorological data using statistical downscaling techniques. It requires fewer input data due to repetitive calculations and is characterized by higher simplicity and efficiency than other models (Heydari Tasheh Kabood et al. 2020). It was used for producing daily maximum and minimum temperature, precipitation, and radiation under the current and future climatic conditions. This model was initially proposed by (Racsko et al. 1991) and then revised and developed by
(Semenov et al. 1998) at the Long Ashton Research Center (Heydari Tasheh Kabood et al. 2020).

The weaknesses of the Markov chain led to the development of this model, which is a randomized model based on the quasi-experimental distribution (Semonov and Stratonovitch 2010). In 2018, the new version of this model (LARS-WG6) was updated and published for downscaling the Coupled Model Intercomparison Project Phase 5 (CIMP5) (Heydari Tasheh Kabood et al. 2020).

In this research, the LARS-WG version 6.0 configured with CMIP5 scenarios is used here to downscale the GCM outputs. LARS-WG is a stochastic weather generator that can simulate weather data at a single site under current and future climate conditions. Climatic conditions of the basin were modeled based on the data collected at Sanandaj and Marivan stations over the last three decades. These two stations were selected with attention to the age, area, and shape of the basin to reflect the entire area's climatic conditions. Two GCMs, namely EC-EARTH and Had-GEM2-ES with tree Representative Concentration Pathway (RCP) 2.6, 4.5, and 8.5, were used to predict the region's climatic data. The characteristics of the GCM models used in this research are described in Table 1 and 
Table 1 The used data characteristics

\begin{tabular}{|c|c|c|c|c|c|c|c|}
\hline & Type & Data & Unit & Resolution & Data & Source & Tool \\
\hline \multirow[t]{5}{*}{ Land use } & \multirow[t]{5}{*}{ Spatial-temporal } & Land use 2013 & \multirow[t]{5}{*}{ meter } & \multirow[t]{5}{*}{$30 \times 30$} & \multirow{5}{*}{$\begin{array}{l}2013- \\
2019-2040\end{array}$} & \multirow[t]{5}{*}{ USGS.gov } & ENVI 5.3 \\
\hline & & Land sat 8-ETM+ & & & & & Arc GIS 10.7 \\
\hline & & Land use 2019 & & & & & \\
\hline & & Land sat 8-OLI & & & & & InVEST 3.8.9 \\
\hline & & Land use 2040 & & & & & \\
\hline \multirow[t]{4}{*}{ Climate } & \multirow{4}{*}{$\begin{array}{l}\text { Climatology and } \\
\text { synoptic data }\end{array}$} & Minimum temperature & \multirow{2}{*}{$\begin{array}{l}\text { Centi- } \\
\text { grade } \\
\text { degree }\end{array}$} & & \multirow[t]{4}{*}{ 1990-2019-2040 } & \multirow{4}{*}{$\begin{array}{l}\text { National meteorological } \\
\text { Organization }\end{array}$} & LARS-WG 6 \\
\hline & & Maximum temperature & & & & & Excel 2019 \\
\hline & & Precipitation & $\mathrm{mm}$ & & & & \\
\hline & & Sunshine & h/day & & & & \\
\hline \multirow[t]{12}{*}{ Water yield } & \multirow[t]{7}{*}{ Spatial } & Precipitation & $\mathrm{mm}$ & \multirow[t]{12}{*}{$30 \times 30$} & \multirow[t]{7}{*}{ 2013-2019-2040 } & Worldclim.org + National & \multirow{7}{*}{$\begin{array}{l}\text { Arc GIS } 10.7 \\
\text { InVEST } 3.8 .9\end{array}$} \\
\hline & & $\begin{array}{l}\text { Average Annual Refer- } \\
\text { ence Evapotranspira- } \\
\text { tion }\end{array}$ & $\mathrm{mm}$ & & & $\begin{array}{l}\text { meteorological Organi- } \\
\text { zation }\end{array}$ & \\
\hline & & $\begin{array}{l}\text { Root restricting layer } \\
\text { depth }\end{array}$ & $\mathrm{mm}$ & & & $\begin{array}{l}\text { FAO.org- FAO (1998b)- } \\
\text { Harmonized world soil } \\
\text { data }\end{array}$ & \\
\hline & & $\begin{array}{l}\text { Plant Available Water } \\
\text { Content }\end{array}$ & & & & & \\
\hline & & Land use/land cover & & & & Processed satellite image & \\
\hline & & basins & & & & National Cartographic & \\
\hline & & Sub-basins & & & & Center & \\
\hline & \multirow[t]{5}{*}{ Table format data } & Lucode & & & \multirow[t]{5}{*}{ 2013-2019-2040 } & & \multirow[t]{5}{*}{ Excel 2019} \\
\hline & & LULC_desc & & & & & \\
\hline & & LULC_veg & & & & & \\
\hline & & Root_depth & $\mathrm{mm}$ & & & & \\
\hline & & $\mathrm{Kc}$ & & & & FAO.org & \\
\hline
\end{tabular}

Fig. 1. In addition, the type and format of the data are presented in the Table 1.

\section{Data}

Various data were used in this study, the characteristics of which are summarized in Table 1.

\section{Land use}

As shown in Fig. 2 and Table 1, land-use modeling was conducted based on changes of two past decades to predicting future changes. Land-use changes in the region were studied using satellite images taken in four 10-year periods. Because of the poor quality of the 1989 and 1999 images of Landsat 5 , these images were removed from the data. Also, the 2009 image of Landsat 7, which had an error, was replaced with the 2013 image of Landsat 8.

Preprocessing Preprocessing includes the image's radiometric and atmospheric correction and mosaicking. In this research, the correction on images was carried out using the radiometric calibration method and quick atmospheric correction in ENVI 5.3 Software (Kourosh Niya et al. 2019). The image mosaicking was conducted by the seamless method. Then for image classification, several algorithms, including maximum likelihood (Effati et al. 2021), neural net, super vector machine, and minimum distance, were used by using 300 samples. Finally, based on the comparison between the result and ground truths, the maximum likelihood is selected as the proper classification method.

Land cover maps identifying spectrally similar pixels can be generated through supervised or unsupervised classification algorithms. In supervised classifications (e.g., decision trees, maximum likelihood, and minimum distance (Kourosh Niya et al. 2020), reference "training" datasets are used to perform the classification (Shrestha et al. 2019). ENVI tool implements the maximum likelihood classification method by calculating the following discriminant functions for each pixel in the image (Richards 1999). Classification accuracy is determined by the overall classification accuracy and kappa coefficient in the ENVI 5.3 software. (Pullanikkatil et al. 2016). There are 
seven land-use types in the Sirvan Basin: built-up, water, forest, agriculture, rangeland, dry farming, and bare land.

\section{Scenario making}

The scenario generator (InVEST 3.8.9) has been used for scenario making. This tool works based on the transition between LULC classes, as defined by the user. The defined transition should be adjusted according to past changes, population growth, and national-provincial policy. The results are based on these inputs; base land use/cover, area of interest, max area to convert (ha), focal land cover code, convertible land cover, and replacement land cover.

In this research, scenarios are created by integrating climate and land use. First, two scenarios are created for land use, include low urbanization (10\% radius expansion of the residential area in legal boundary and forest cover conversion by $3 \%$ ) and high urbanization (20\% radius expansion of the residential area in legal boundary and forest cover conversion by $6 \%$ ). Then each of these scenarios is combined with two climatic scenarios, moderate climate change (an increase of temperature by $1.25^{\circ} \mathrm{c}$ and reduction of precipitation by $8 \%$, according to IPCC scenarios and model prediction) and severe climate change (an increase of temperature by $2.5^{\circ} \mathrm{c}$ and reduction of precipitation by $10 \%$ ) to create four final scenarios (Fig. 3). Increasing temperature in two scenarios implies precipitation and evapotranspiration maps as inputs to the water yield model.

\section{Water yield ecosystem service}

The purpose of the prior stages of the study was to prepare the required data for modeling the water yield of the Sirvan Basin. Thus, the results of these stages were used to produce inputs for the InVEST water yield model. These inputs include precipitation, reference evapotranspiration, depth to root restricting layer, land-use, plant available water content, and evapotranspiration coefficient of different land-use.

To evaluate, annual water yield, the Integrated Valuation of Ecosystem Services and Tradeoffs (InVEST) toolkit was used, developed by the Natural Capital Project (Jafarzadeh et al. 2019). The InVEST Water Yield model estimates the relevant contributions of water from different parts of a landscape, presenting a vision into how changes in land-use patterns affect annual surface water yield. It estimates ecosystem water production using water balance. The precipitation and actual evapotranspiration difference in a grid cell are the water supply (Lang et al. 2017). The model required

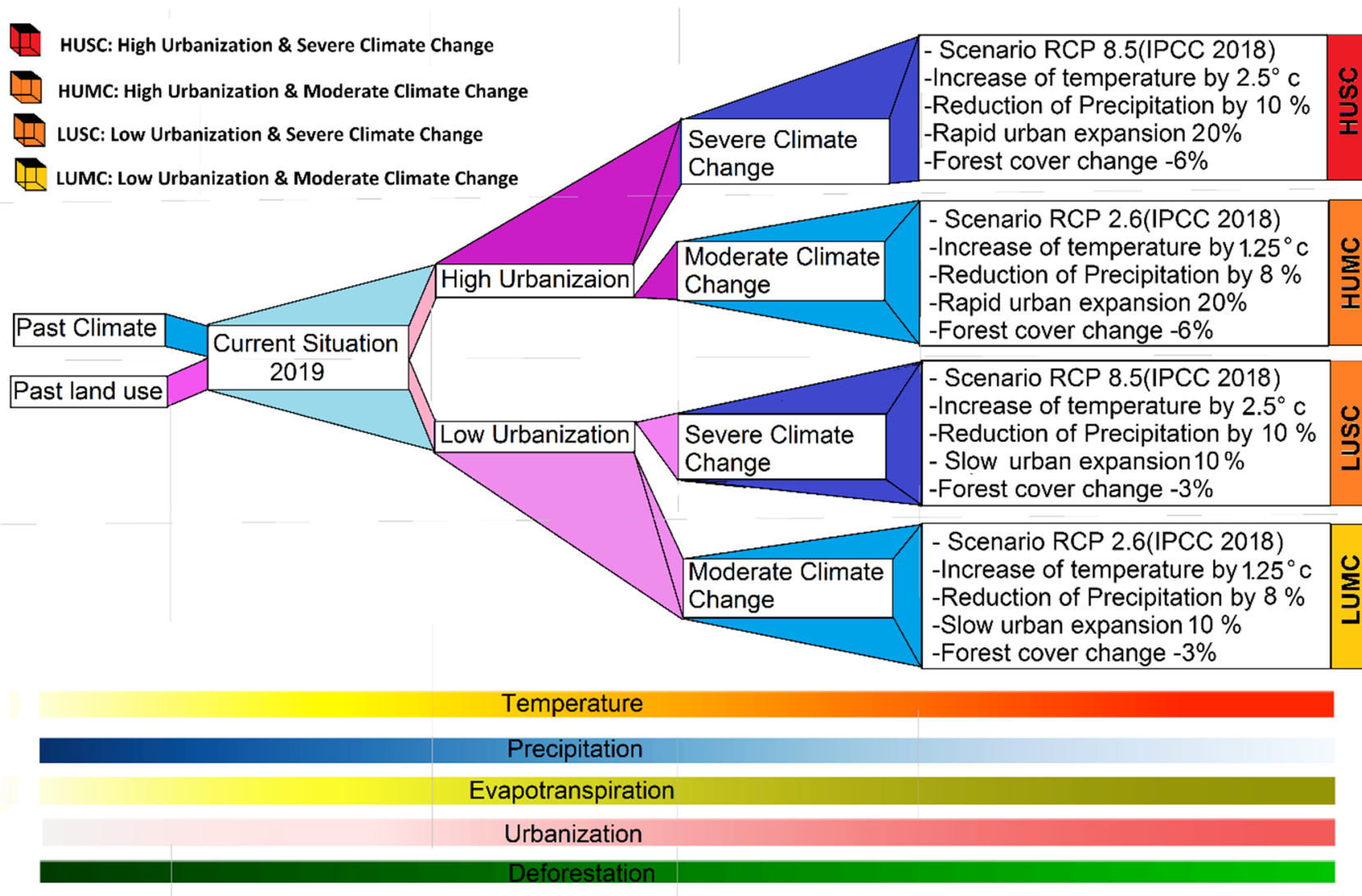

Fig. 3 The different scenarios generated 
Table 2 Precipitation records and forecasts for Marivan and Sanandaj stations

\begin{tabular}{lllllllllllll}
\hline MARIVAN & Jan & Feb & Mar & Apr & May & Jun & Jul & Aug & Sep & Oct & Nov & Dec \\
\hline 1990-2019 & 156.66 & 150.73 & 146.2 & 113.87 & 46.92 & 2.78 & 1.03 & 0.46 & 2.85 & 43.83 & 117.99 & 136.57 \\
Hadgem-rcp26 & 172.68 & 145.68 & 140.1 & 137.99 & 49.49 & 6.36 & 1.14 & 0.47 & 6.68 & 37.72 & 110.43 & 158.65 \\
Hadgem-rcp85 & 145.35 & 149.19 & 155.69 & 106.6 & 52.78 & 3.86 & 0.59 & 0.62 & 7.67 & 39.57 & 103.04 & 140.59 \\
\hline SANANDAJ & Jan & Feb & Mar & Apr & May & Jun & Jul & Aug & Sep & Oct & Nov & Dec \\
\hline 1990-2019 & 43.76 & 44.36 & 57.43 & 62.68 & 31.13 & 2.26 & 1.5 & 0.11 & 1.09 & 27.53 & 60.58 & 42.64 \\
Hadgem-rcp26 & 50.12 & 43.69 & 56.99 & 59.15 & 27.5 & 1.8 & 0.63 & 0.15 & 2.99 & 30.16 & 63.56 & 45.3 \\
Hadgemrcp85 & 29.85 & 48.22 & 43.29 & 47.78 & 27.66 & 2.24 & 2.6 & 0.03 & 1.11 & 36.98 & 52.62 & 47.87 \\
\hline
\end{tabular}

eight input datasets (Table 2, Fig. 5), encompassing six spatial map data and two ones taken by coefficients (Jafarzadeh et al. 2019).

After estimating water yield, the next step consisted in estimating water scarcity/surplus of the basin. For this purpose, it was necessary to assess water consumption of different land-uses and create the water consumption table needed as model input for this stage. This estimation had to be conducted only for land uses with non-natural water consumption, i.e., consumption in residential areas, industrial areas, health, and agriculture. This estimation was performed based on the available statistics on per capita water consumption and water needs for agricultural products. The amounts introduced to the model in cubic meters per unit area and then calculated for each sub-basin. Then, the water scarcity/surplus of the sub-basins was obtained by deducting consumption from water yield.

\section{Results}

\section{Climate modeling}

The data showed that the precipitation in the area has had a generally decreasing trend over the last three decades until 2017 but has shown the opposite trend in later years because of huge precipitation in 2018 and 2019. However, the models predicted a general decrease in precipitation from 2020 to 2040. The extent of precipitation reduction was the same in the two models but different in the two scenarios. The model also predicted that both stations and the region, in general, will experience rising temperatures. However, given the cold climate of the region, this temperature increase is expected to be less than those in IPCC scenarios $\left(2\right.$ and $3.5^{\circ} \mathrm{C}$ ) (Table 2). The model outputs also predicted a change in the monthly precipitation distribution.

\section{Land-use scenarios}

The satellite images analysis showed an increase in the area of built-up, agriculture, and rangeland and water bodies, and a decrease in the area of forest and barren land. The expansion of water bodies surfaces is due to the construction of several dams in the region, particularly the Darian, Garan, and Azad dams, which became operational in 2019. The expansion of built-up areas is related to population growth and infrastructure development. The expansion of agricultural lands is caused by the conversion of forests and rangelands to farmlands. The shrinking of forested lands can also be attributed to timber production and the conversion of forests to rainfed vineyards. Despite the large-scale conversion and degradation of rangelands, the region had more rangelands in 2019 than in 2013. However, this is because precipitation was far lower in 2013 than in 2019. The decrease in barren lands can also be attributed to 2019 being a wet year, which has led to the temporary conversion of many barren lands into rangelands (Figs. 4, 5).

Table 3 shows the details of the two land-use scenarios generated for 2040 with this tool. These two scenarios, which were called "low urbanization" and "high urbanization," represent the effect of urbanization on built-up areas, including urban, rural, industrial areas, transport infrastructure, and so on, as well as the conversion of forests, rangelands, and deserts to residential and agricultural lands. The degradation/conversion zone grows from the margins of existing zones by a magnitude that depends on the nature of the scenario and is expressed as a percentage of original and target land-uses (Fig. 5). In the moderate climate change scenario, it was assumed that the region would experience an $8 \%$ decrease in average long-term precipitation and a $1.25{ }^{\circ} \mathrm{C}$ increase in average temperature, which will result in a $3.5 \%$ increase in evapotranspiration rate. In the severe climate change scenario, it was assumed that there would be a $10 \%$ decrease in average long-term precipitation and a $2.5^{\circ} \mathrm{C}$ increase in average temperature, which will result in a $5.5 \%$ increase in evapotranspiration rate (Table 3 ).

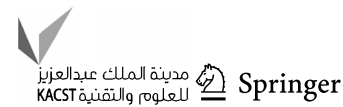




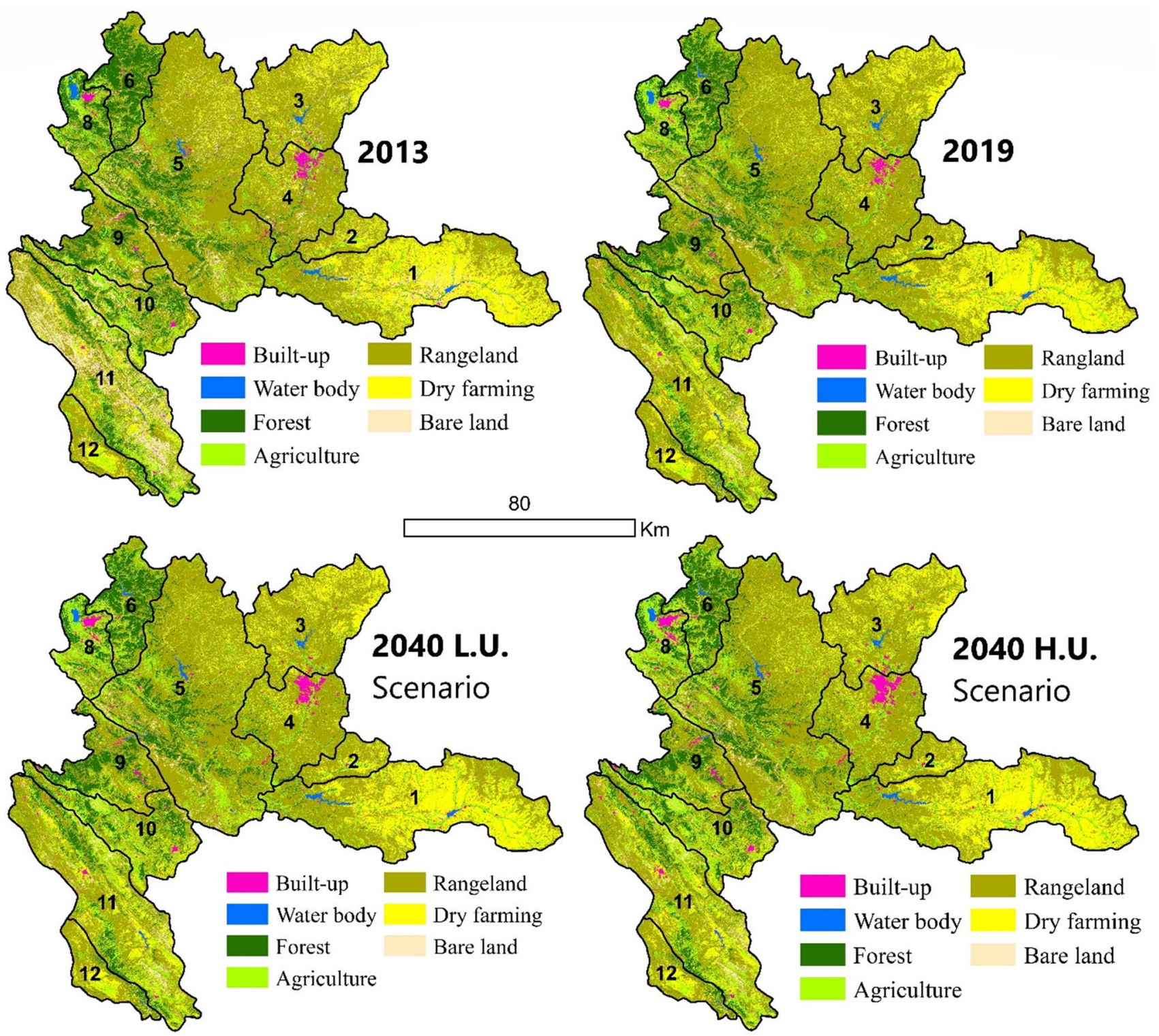

Fig. 4 Land-use changes in Sirvan basin

\section{Water ecosystem services}

Sirvan Basin has 11 sub-basins which are numbered by the national water resources management center (Fig. 1). The water yield figures obtained for this basin and its sub-basins are given in Table 4 and Fig. 6 . The results showed that the water yield of the basin has been 3498 million $\mathrm{m}^{3}$ in 2013 and reached 5381 million $\mathrm{m}^{3}$ in 2019. After examining the model inputs and outputs, it was found that the main reason for this huge difference between water yields of 2013 and 2019 is the roughly 30\% higher precipitation in the latter year. Using the developed model, the 2040 water yield was predicted to be 3795 million $\mathrm{m}^{3}$ under the first scenario (Low Urbanization + Moderate Climate Change;
LUMC), 3635 million $\mathrm{m}^{3}$ under the second scenario (Low Urbanization + Severe Climate Change; LUSC), 3761 million $\mathrm{m}^{3}$ under the third scenario (High Urbanization + Moderate Climate Change; HUMC), and 3601 million $\mathrm{m}^{3}$ under the fourth scenario (High Urbanization + Severe Climate Change; HUSC).

\section{Water shortage/surplus in Sirvan Basin and sub-basins}

As shown in Fig. 7, the entire basin has higher precipitation and lower evapotranspiration in MC scenarios than in S.C. scenarios, which results in lower water yields in the latter. Also, LU scenarios have lower water consumption, and MC scenarios have higher water surplus (Fig. 7). 


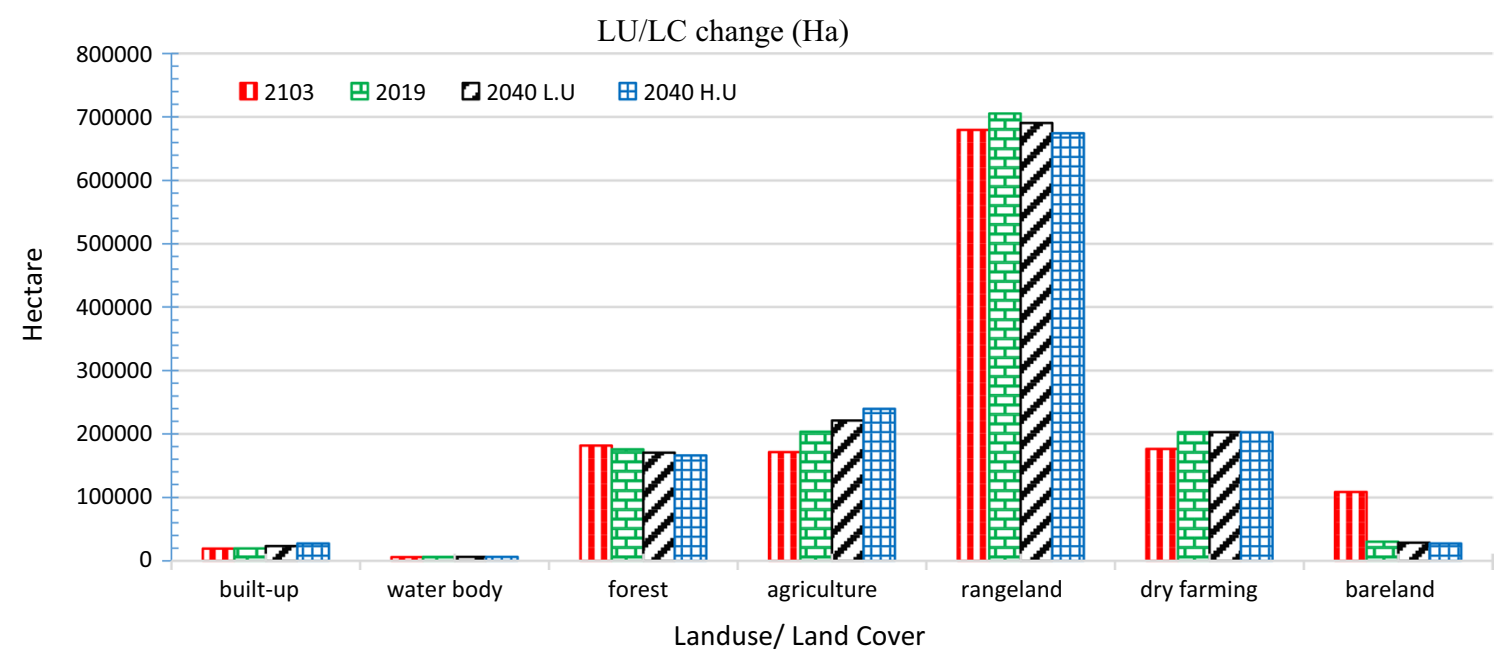

Fig. 5 land-use changes (2013-2019-2040)

Table 3 Specifications of the defined scenarios

\begin{tabular}{|c|c|c|c|c|c|}
\hline & Land use & & Climate & & Scenarios \\
\hline 1 & Low urbanization & $3,4,5,6,7$ to $1 \geq 10 \%$ add to 1 & Moderate climate change & $\begin{array}{l}8 \% \text { decrease precipitation (based on } \\
\text { modeling result) } 1.25^{\circ} \mathrm{C} \text { increase } \\
\text { temperature leads to increase evapo- } \\
\text { transpiration by } 3.5 \%\end{array}$ & LUMC \\
\hline 2 & & 3,5 to $4 \geq 4 \%$ remove from 3 and 5 & Severe climate change & & LUSC \\
\hline 3 & High urbanization & $3,4,5,6,7$ to $1 \geq 20 \%$ add to 1 & Moderate climate change & & HUMC \\
\hline 4 & & $\begin{array}{l}3,5,7 \text { to } 4 \geq 5 \% \text { remove from } 3,5 \\
\text { and } 7\end{array}$ & Severe climate change & $\begin{array}{l}10 \% \text { decrease precipitation } 2.5^{\circ} \mathrm{C} \\
\text { increase temperature leads to } \\
\text { increase evapotranspiration by } 5.5 \%\end{array}$ & HUSC \\
\hline
\end{tabular}

Table 4 Water yield in the sub-basins of the Sirvan basin (million cubic meters/year)

\begin{tabular}{lrrrrrr}
\hline SUB-basins & \multicolumn{1}{c}{ 2013 } & \multicolumn{1}{c}{ 2019 } & 2040 LUMC & 2040 LUSC & 2040 HUMC & 2040 HUSC \\
\hline SUB.W1 & 404.73 & 631.79 & 459.52 & 448.19 & 456.34 & 445.05 \\
SUB.W2 & 66.40 & 100.79 & 72.38 & 70.83 & 71.76 & 70.21 \\
SUB.W3 & 283.78 & 410.37 & 300.04 & 294.30 & 295.94 & 290.23 \\
SUB.W4 & 211.39 & 320.59 & 223.95 & 217.81 & 220.45 & 214.38 \\
SUB.W5 & 973.87 & 1426.28 & 1000.79 & 963.67 & 994.17 & 957.01 \\
SUB.W6 & 211.75 & 295.65 & 204.47 & 195.44 & 203.30 & 194.23 \\
SUB.W8 & 199.12 & 278.70 & 194.50 & 182.99 & 191.75 & 180.09 \\
SUB.W9 & 262.02 & 396.97 & 275.50 & 260.65 & 273.41 & 258.50 \\
SUB.W10 & 265.14 & 435.63 & 298.80 & 281.85 & 295.53 & 278.58 \\
SUB.W11 & 514.90 & 906.90 & 638.58 & 600.62 & 632.32 & 594.47 \\
SUB.W12 & 105.04 & 177.42 & 126.57 & 119.39 & 126.03 & 118.85 \\
Total & 3498.14 & 5381.06 & 3795.09 & 3635.74 & 3761.00 & 3601.59 \\
\hline
\end{tabular}

From the precipitation, evapotranspiration, water yield, water consumption, and water surplus results plotted in the above diagram, it can be approximately concluded that precipitation is a major determinant of the amount of water yield in the basin. The Fig. 7 shows a high degree of similarity between precipitation and water yield curves, but an inverse relationship between precipitation and evapotranspiration curves. With the increase in precipitation from 2013 to 2019, water yield has also increased. After examining the historical precipitation data, it was found that precipitation 

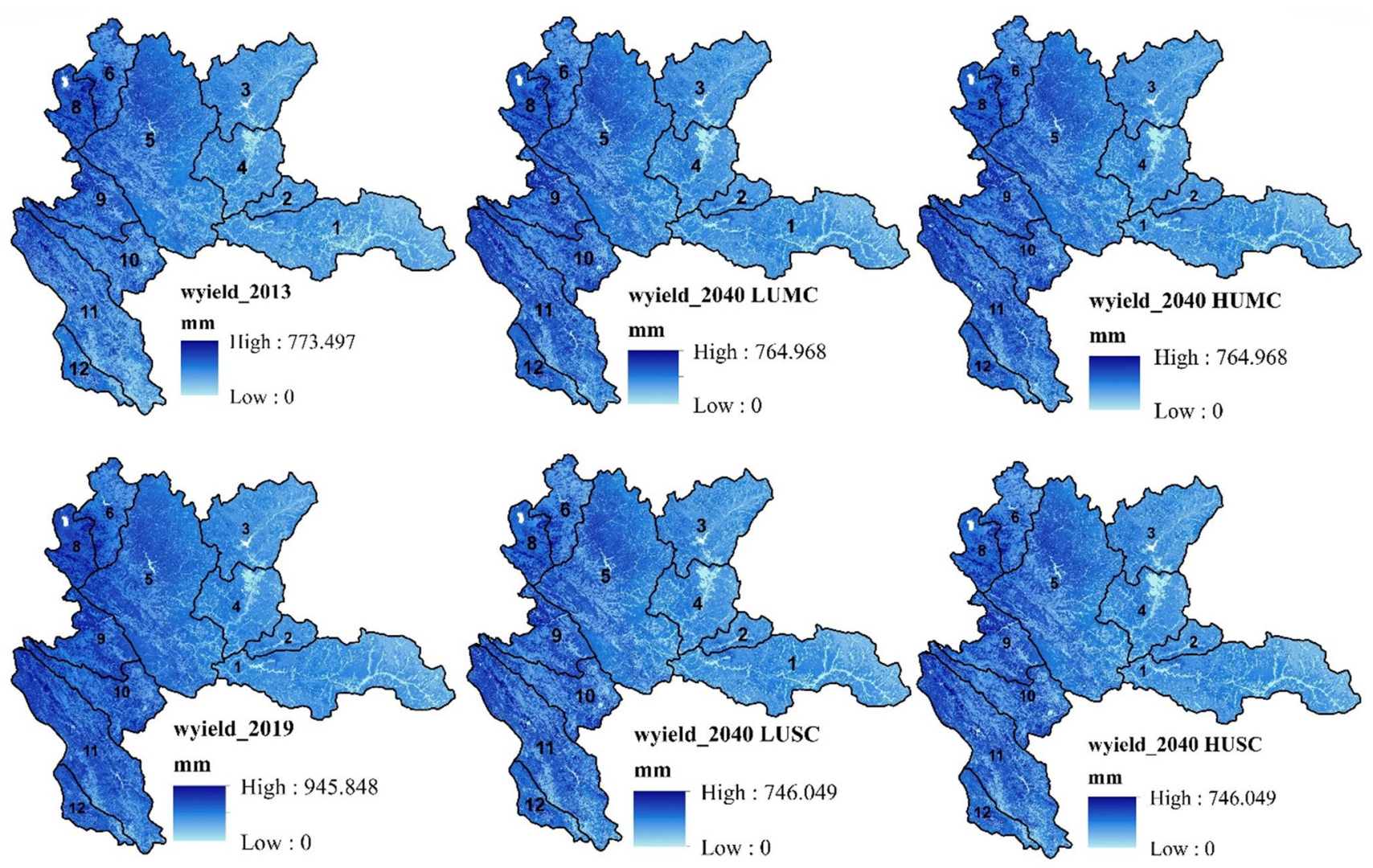

Fig. 6 Water yield under different scenarios

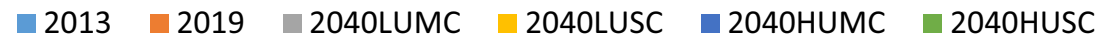

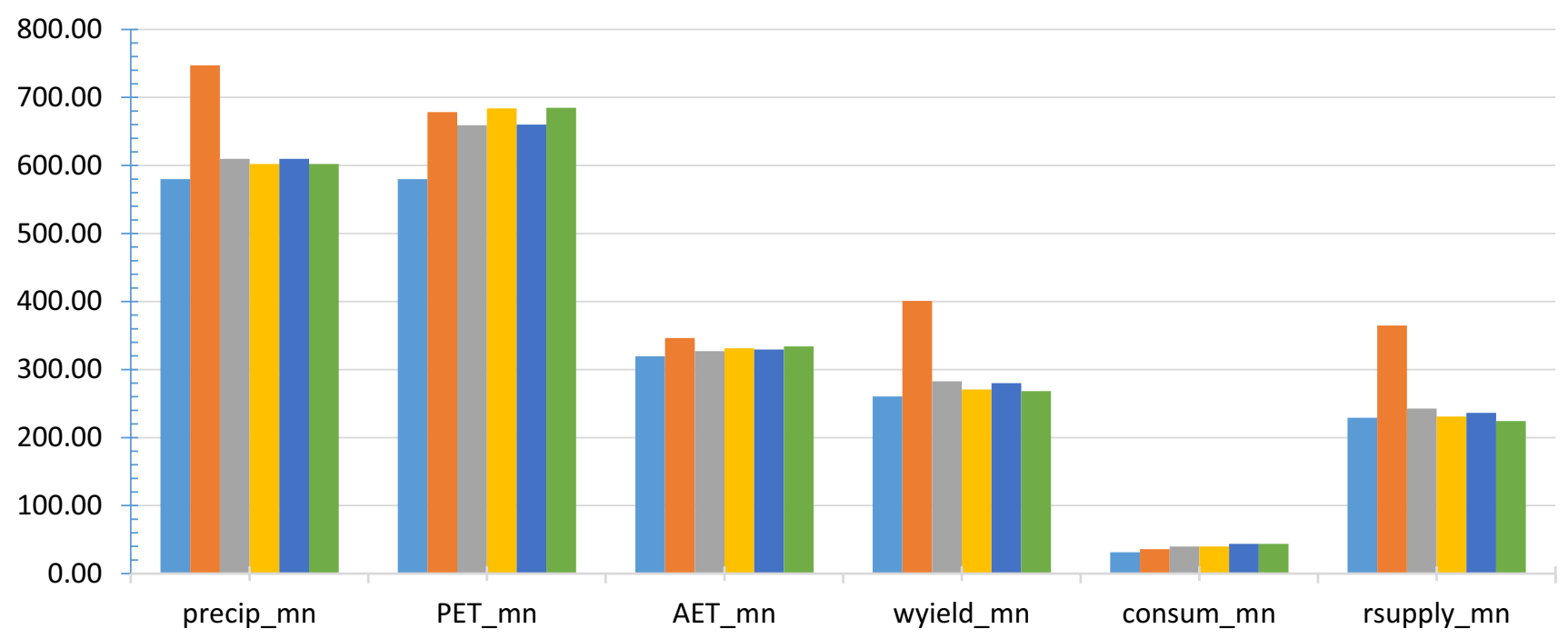

Fig. 7 Comparison of model parameters in different scenarios

in 2013 has been lower than the region's long-term average, which means that this year belongs to a drought period. There was less reduction in precipitation from the long-term average in the MC scenario and less increase in evapotranspiration, leading to higher water yield than the SC scenario. The results of water yield modeling and prediction under 
different scenarios showed that climatic parameters, such as precipitation, have greater impacts on water yield than land-use changes, which is consistent with the findings of Yin et al. (2020), Wu et al. (2017), Kim and Jung (2020), but is inconsistent with the findings of Shirmohammadi et al. (2020). This inconsistency in the findings of different studies highlights the need for further research in this area.

\section{Sensitivity analysis}

The sensitivity of model outputs to different inputs was measured by defining a scenario. In this scenario, the model inputs were changed such that the type and extent of model sensitivity to each parameter can be determined. This method was also used to make a quantitative assessment of the impact of each input. The four groups of parameters used in the four phases of sensitivity analysis are listed in Table 4. These four groups of parameters were: (1) climatic and land-use parameters of 2013, (2) climatic and land-use parameters of 2019, (3) climatic parameters of 2013 and land-use parameters of 2019, and (4) climatic parameters of 2019 and land-use parameters of 2013 (Table 5, Fig. 8).

In the first phase, where the model parameters were selected from the same year, the results showed a $29 \%$ increase in precipitation, an $8 \%$ increase in actual evapotranspiration, and a 54\% increase in water yield. In the second phase [2013 (19)], where the 2013 land-use data of the previous model were replaced with the 2019 land-use data, precipitation remained the same, actual evapotranspiration increased by $32 \%$, and water yield decreased by $39 \%$. In the third phase [2019 (13)], where the 2013 land-use data were placed in the 2019 model, precipitation remained the same, actual evapotranspiration increased by $38 \%$, and water yield decreased by $29 \%$. In the fourth phase, where the landuse data of the two periods were swapped, precipitation increased by $29 \%$, actual evapotranspiration increased by $13 \%$, and water yield increased by $71 \%$.

The large changes in land use from 2013 to 2019 included a 6000-hectare decrease in forest lands (due to degradation/ conversion), an 80,000-hectare reduction in barren lands (due to increased precipitation), a 30,000-hectare increase in agricultural lands, a 26,000-hectare increase in rangelands, and a 27,000-hectare increase in irrigation farmlands. These changes sum up to 170,000 hectares, equivalent to $12 \%$ of the total area of the studied catchment.

\section{Discussion}

A major challenge in distinguishing the effects of climate change and land-use changes and their interactions is the difficulty of producing a reasonably conclusive estimate of future land-use changes, especially at spatial scales needed for ecosystem, basin, and water supply management (Martin et al. 2017). The method used in this study, which involved

Table 5 Sensitivity analysis of the model

\begin{tabular}{|c|r|r|r|r|r|r|}
\hline OBJECTID & $\mathbf{2 0 1 3}$ & $\mathbf{2 0 1 9}$ & Changes (\%) & $\mathbf{2 0 1 9}$ & $\mathbf{2 0 1 9 ( 1 3 )}$ & changes (\%) \\
\hline Precip_mn & 580 & 747 & 29 & 747 & 747 & 0 \\
\hline AET_mn & 319 & 346 & 8 & 346 & 479 & 38 \\
\hline Wyield_mn & 261 & 401 & 54 & 401 & 268 & 29 \\
\hline OBJECTID & $\mathbf{2 0 1 3}$ & $\mathbf{2 0 1 3}(\mathbf{1 9})$ & Changes (\%) & $\mathbf{2 0 1 3}(\mathbf{1 9 )}$ & $\mathbf{2 0 1 9 ( 1 3 )}$ & changes (\%) \\
\hline Precip_mn & 580 & 580 & 0 & 580 & 747 & 29 \\
\hline AET_mn & 319 & 423 & 32 & 423 & 479 & 13 \\
\hline Wyield_mn & 261 & 157 & -39 & 157 & 268 & 71 \\
\hline
\end{tabular}
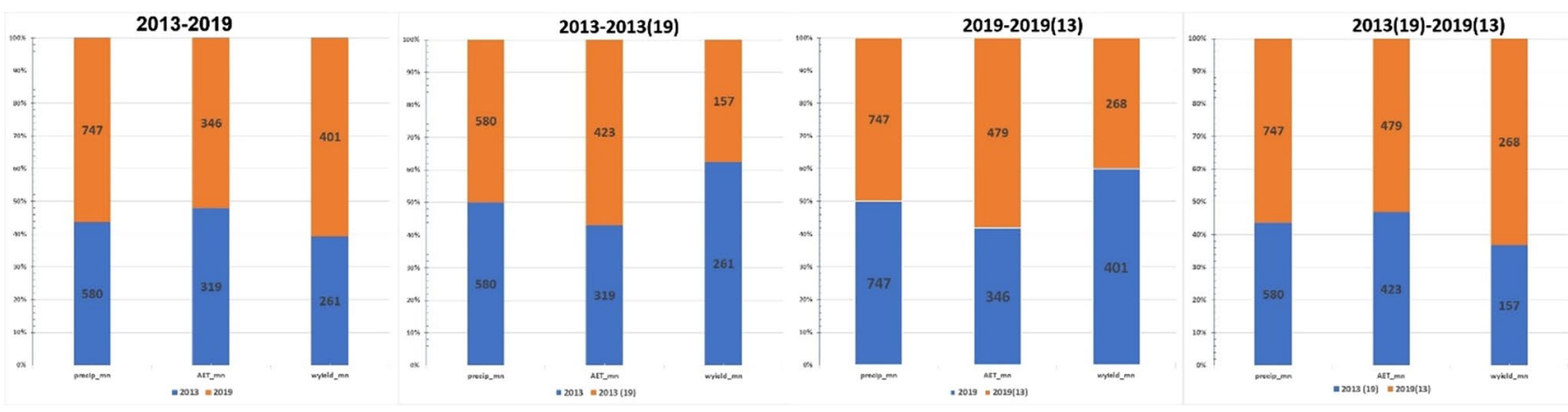

Fig. 8 sensitivity analysis 
scenario making based on population growth and other socio-economic factors rather than making forecasts based on past trends, proved very effective in dissecting the effects of land-use changes and climate change.

To develop a comprehensive framework, which can integrate climate and land-use factors in decision-making simultaneously, the incorporation of different models is needed. This work has many complexities and requires sufficient knowledge of all aspects of these tools and models. In this regard, in this research, various tools were used to prepare data and model. Temporal monitoring should also be considered to form a correct decision regarding recognizing the past and current situation. While this procedure can enhance the quality and comprehensiveness of studies, it can also increase uncertainty. Since one of the principal cases in such research is land use data, and these data with proper temporal and spatial scale are rarely available, remote sensing techniques are a suitable option. Image processing should be done with reasonable accuracy and precision. After comparing the different classification methods results, the maximum likelihood method was selected. Future planning requires scenario-making for land-use change, which is developed according to multiple factors such as population growth, urban growth, agricultural development, conservation policies, and other influential factors. Most past research has simulated the future changes based on the past trend changes. In these approaches, only one scenario is generated, limiting the analysis of the effects of different policies, based on the status of the involved factors.

Climate modeling needs past data to train and forecasting future changes. General circulation models and IPCC scenarios were used to achieve this, and the LARS-WG tool was selected for downscaling. These models and tools can provide valuable information to planners.

The points considered in a scenario making included the conversion and degradation of land uses, especially forests (Karimi et al. 2018) (in the western half of the region), population growth and the resulting urban development, reverse migration from cities to villages and the trend of people building second homes in the countryside (which not only boosts rural construction but also affects agriculture), and forest fires (Jamshid Bakhtar et al. 2013).

As mentioned, the results showed that climatic parameters affect water yield more than land-use changes (Saddique et al. 2020). Land-use changes can change water yield by changing soil infiltration rate, root depth, plant available water content, soil texture, and evapotranspiration rate (Shirmohammadi et al. 2020). Conversion of forest lands to other land-uses plays a particularly important role in increasing runoff. Climatic changes have a more specific mechanism of affecting water yield than land-use changes. A change in precipitation directly affects water yield. Also, temperature changes affect water yield indirectly by changing the evapotranspiration rate. From the results of this study, it can be concluded that land-use changes and climatic changes have a roughly 1:3 effect on the water yield of the studied basin. In other words, the water yield of this basin is influenced three times more by climatic factors than by land-use factors.

The model (InVEST) used in this study has a number of limitations that can make the results uncertain. One of these limitations is related to the type of input data. For example, precipitation and evapotranspiration are both annual inputs, and their seasonal changes must be applied to the model using a seasonality factor (Hamel and Guswa 2015). Another limitation of this model is the difficulty of considering past and future changes (Yin et al. 2020), which in this study was addressed by modeling the past and producing forecasts for the future. Also, the use of global data in places where local data are not available may reduce the accuracy of this model (Kim and Jung 2020). This study addressed this problem by assessing the accuracy of data based on available local data.

\section{Conclusion}

The hydrological balance of the Sirvan Basin is influenced by a variety of factors, including climate change, land-use changes, population growth, etc. Since this basin is one of the sub-basins of Tigris, which makes it transnational, development in this area should be planned with attention to the capacity of the basin and international commitments in terms of downstream hydrological balance. The first requirement for making any kind of plan for any basin is to gather sufficient knowledge of its features and condition in the past, present, and future. Indeed, a large number of methods and tools have been developed for this very same purpose. Given the complexities and uncertainties involved in the mutual effects of climate change and land-use changes on basins, the simultaneous study of these effects will require careful consideration of the inputs to be used and the relationships between them. The modeling and forecasting conducted in this study showed that the water yield of the Sirvan Basin currently exceeds the needs of the area.

It should be noted that further studies are needed to determine whether the current water yield of this basin is also enough to fulfill downstream water rights, an issue that was not explored in this study. Given the location of several large population centers, including Sanandaj, Marivan, and Javanroud in sub-basins 4,8 , and 10 of these basins, the conclusion made for the entire basin does not necessarily apply to its sub-basins. With the population growth and horizontal expansion of these cities and the consequent land-use changes, water yield in these sub-basins will not be able to keep up with the rising demand. Even today, water demand in these sub-basins is met by transferring water from Vahdat 
and Azad dams to Sanandaj and from Garan dam to Marivan. Given the region's population growth and agricultural development and the drying of its climate, the Sirvan Basin and especially the mentioned sub-basins are very likely to encounter more water supply problems in the future. One of the most important issues of this transboundary basin is the plans to construct several dams in the area for hydropower generation and inter-basin water transfer, which will extensively change the hydrological regime of the region. Also, it is crucial to take some measures to ensure proper adaptation to the effects of climate change in this area. Given the extensive change in the forest lands of the western parts of the region in recent years, which have been mostly in the form of appropriation for horticulture, it is recommended to implement stricter control measures and more extensive promotional programs for preserving oak forests. It is also recommended to develop and adopt a program for the optimal management of water resources in the region's agricultural sector, as it currently operates with very low water efficiency.

Acknowledgements We are pleased to appreciate the Iran National Science Foundation (INSF) for the financial support (No: 98012340) of the study.

Authors' contributions All authors made substantial contributions to the conception and design. J.B dealt with data gathering, analysis, and interpretation with the support of B.M, H.R.J, A.N, and D.G. J.B processed the experimental data, performed the analysis, wrote the manuscript draft, and designed the figures. B.M. and H.R.J supervised the manuscript, aided in interpreting the results, worked on the manuscript, and revised the article critically for important intellectual content. A.N and D.G participated as advisors to finalizing the framework and conceptualizing the subject. All authors gave final approval to the version to be submitted and to all revised versions.

Funding This research funded by Iran National Science Foundation (INSF).

Availability of data and materials Data available on request from the authors.

Code availability InVEST, LARS, ArcGIS, Excel.

\section{Declarations}

Conflict of interest The authors declare that they have no conflict of interest.

Open Access This article is licensed under a Creative Commons Attribution 4.0 International License, which permits use, sharing, adaptation, distribution and reproduction in any medium or format, as long as you give appropriate credit to the original author(s) and the source, provide a link to the Creative Commons licence, and indicate if changes were made. The images or other third party material in this article are included in the article's Creative Commons licence, unless indicated otherwise in a credit line to the material. If material is not included in the article's Creative Commons licence and your intended use is not permitted by statutory regulation or exceeds the permitted use, you will need to obtain permission directly from the copyright holder. To view a copy of this licence, visit http://creativecommons.org/licenses/by/4.0/.

\section{References}

Al-Faraj FAM, Scholz M (2015) Impact of upstream anthropogenic river regulation on downstream water availability in transboundary river watersheds. Int J Water Resour Dev 31(1):28-49. https://doi.org/10.1080/07900627.2014.924395

Afzal M, Ragab R (2020) Assessment of the potential impacts of climate change on the hydrology at catchment scale: modelling approach including prediction of future drought events using drought indices. Appl Water Sci 10:215. https://doi.org/10. 1007/s13201-020-01293-1

Atumane A, Cabral P (2021) Integration of ecosystem services into land use planning in mozambique. Ecosyst, People 17(1):165177. https://doi.org/10.1080/26395916.2021.1903081

Aliani H, Malmir M, Sourodi M et al (2019) Change detection and prediction of urban land-use changes by C.A.-Markov model (case study: Talesh County). Environ Earth Sci 78:546. https://doi.org/ 10.1007/s12665-019-8557-9

Amini MR, Shetaee S, Ghazanfari H, Moayeri MH (2009) Change detection of Zagros forests extent by using airborne photo satellite images (case study: Bane forests). JASNR 15(2):10-20

Ashnani MHM, Danehkar A, Makhodoum M, Majed V (2018) Integrating the concept of ecosystem services and values in land use planning. In: IOP conference series: earth and environmental science (EES), vol 167. IOP Publishing, Barcelona, p 012026

Bagstad KJ, Villa F, Batker D, Harrisoncox J, Voigt B, Johnson GW (2015) From theoretical to actual ecosystem services: mapping beneficiaries and spatial flows in ecosystem service assessments. Ecol Soc 19(2):64-69. https://doi.org/10.5751/ES-06523-190264

Bounoua L, Nigro J, Zhang P, Thome K, Lachir A (2018) Mapping urbanization in the United States from 2001 to 2011. Appl Geogr 90:123-133

Bozorg-Haddad O, Zolghadr-Asli B, Sarzaeim P, Aboutalebi M, Chu X, Loáiciga HA (2020) Evaluation of Water shortage crisis in the middle east and possible remedies. J Water Supply: Res TechnolAqua 69(1):85-98. https://doi.org/10.2166/aqua.2019.049

Di Marino M, Tiitu M, Lapintie K, Viinika A, Kopperoinen L (2019) Integrating green infrastructure and ecosystem services in land use planning. Results from two Finnish case studies. Land Use Policy 82:643-656. https://doi.org/10.1016/j.landusepol.2019. 01.007

Effati F, Karimi H, Yavari A (2021) Investigating effects of land use and land cover patterns on land surface temperature using landscape metrics in the city of Tehran, Iran. Arab J Geosci 14:1240. https://doi.org/10.1007/s12517-021-07433-4

Hamel P, Guswa A (2015) Uncertainty analysis of a spatially-explicit annual water-balance model: case study of the Cape Fear catchment, N.C. Hydrol Earth Syst Sci. 10.5194/hess-19-839-2015

Hansen R, Pauleit S (2014) From multifunctionality to multiple Ecosystem Services? A conceptual framework for multifunctionality in green infrastructure planning for urban areas. Ambio 43(4):516-529. https://doi.org/10.1007/s13280-014-0510-2

Heydari Tasheh Kabood S, Hosseini SA, Heydari Tasheh Kabood A (2020) Investigating the effects of climate change on stream flows of Urmia Lake basin in Iran. Model Earth Syst Environ 6:329339. https://doi.org/10.1007/s40808-019-00681-0

Jafarzadeh A, Mahdavi A, FallahShamsi R, Yousefpour R (2019) Annual water yield estimation for different land uses by GIS-based

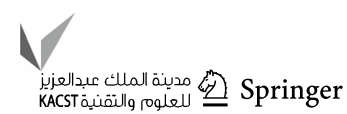


InVEST model (case study: Mish-khas Catchment, Ilam Province, Iran). J Rangel Sci 9(1):1-12

Jamshidi Bakhtar A, Sagheb-Talebi K, MarviMohajer M, Haidari M (2013) The impact of fire on the forest and plants diversity in Iranian Oak forest. Int J Adv Biol Biomed Res 1(3):273-284

Karimi H, Jafarnezhad J, Khaledi J, Ahmadi P (2018) Monitoring and prediction of land use/land cover changes using CA-Markov model: a case study of Ravansar County in Iran. Arab J Geosci 11:592. https://doi.org/10.1007/s12517-018-3940-5

Khan Hasani M, Sharifi M, Tavakoli A (2008) Using aerial photos in estimation of destruction rate of Chahrzobor forests in Kermanshah province. IJFPR 15(2):105-114

Kim S-W, Jung Y-Y (2020) Application of the InVEST model to quantify the water yield of North Korean Forests. Forests 11:804. https://doi.org/10.3390/f11080804

Kourosh Niya A, Huang J, Kazemzadeh-Zow A, Karimi H, Hamidreza., Keshtkar \& BabakNaimi. (2020) Comparison of three hybrid models to simulate land use changes: a case study in Qeshm Island. Iran Environ Monit Assess 192:302. https://doi. org/10.1007/s10661-020-08274-6

Kourosh Niya A, Huang J, Karimi H, Keshtkar H, Naimi B (2019) Use of intensity analysis to characterize land use/cover change in the biggest Island of Persian Gulf, Qeshm Island, Iran. Sustainability 11:4396. https://doi.org/10.3390/su11164396

Maes J, Teller A, Erhard M, Condé S, Vallecillo S, Barredo JI, Paracchini ML, Abdul Malak D, Trombetti M, Vigiak O et al (2020) Mapping and assessment of ecosystems and their services: an EU ecosystem assessment. Publications Office of the European Union, Ispra

Mahdavi A (2010) IRS-1C image data applications for land use/land cover mapping in Zagros region, case study: Ilam watershed. West Iran CJES 8(1):35-41

Mansouri Daneshvar MR, Ebrahimi M, Nejadsoleymani H (2019) An overview of climate change in Iran: facts and statistics. Environ Syst Res 8:7. https://doi.org/10.1186/s40068-019-0135-3

Mugiraneza T, Ban Y, Haas J (2019) Urban land cover dynamics and their impact on ecosystem services in Kigali, Rwanda using multi-temporal Landsat data. Remote Sens Appl Soc Environ 13:234-246. https://linkinghub.elsevier.com/retrieve/pii/S2352 938518300776

Munoth P, Goyal R (2020) Impacts of land use land cover change on runoff and sediment yield of Upper Tapi River Sub-Basin India. Int J River Basin Manage 18(2):177-189. https://doi.org/10.1080/ 15715124.2019.1613413

Nikodinoska N, Paletto A, Pastorella F, Granvik M, Franzese PP (2018) Assessing, valuing and mapping ecosystem services at city level: the case of Uppsala (Sweden). Ecol Model 368:411-424. https:// linkinghub.elsevier.com/retrieve/pii/S0304380017302478

Pachauri RK et al (2014) Climate change 2014: synthesis report. Contribution of Working Groups I, II and III to the fifth assessment report of the Intergovernmental Panel on Climate Change. IPCC

Racsko P, Szeidl L, Semenov M (1991) A serial approach to local stochastic weather models. Ecol Model 57(1):27-41

Ragno E et al (2018) Quantifying changes in future intensity-durationfrequency curves using multimodel ensemble simulations. Water Resources Research

Rezaee Moghadam M, Rezaee Banafshe M, FeyziZade B, Nazm Far $\mathrm{H}$ (2010) Classification of land use/cover based on objectoriented techniques and satellite images (case study: Azarbayjan-egharbi province). JWMR 87:20-35

Richards JA (1999) Remote sensing digital image analysis. Springer, Berlin, p 240

Rozas-Vásqueza D, Fürst C, Geneletti D (2019) Integrating ecosystem services in spatial planning and strategic environmental assessment: the role of the cascade model. Environ Impact Assess Rev 78:106291. https://doi.org/10.1016/j.eiar.2019.106291

Saddique N, Mahmood T, Bernhofer C (2020) Quantifying the impacts of land use/land cover change on the water balance in the afforested River Basin. Pakistan. Environ Earth Sci 79:448. https://doi. org/10.1007/s12665-020-09206-w

Semenov MA, Brooks RJ, Barrow EM, Richardson CW (1998) Comparison of the WGEN and LARSWG stochastic weather generators in diverse climates. Clim Res 10:95-107

Shahkooeei E, Arekhi S, NajafiKani A (2014) Remote sensing and GIS for mapping and monitoring land cover and land use changes using support vector machine algorithm (case study: Ilam dam watershed). Res J Appl Basic Sci 8(4):464-473

Shirmohammadi B, Malekian A, Salajegheh A et al (2020) Impacts of future climate and land use change on water yield in a semiarid basin in Iran. Land Degrad Dev 2020(31):1252-1264. https://doi. org/10.1002/ldr.3554

Shrestha M, Leigh L, Helder D (2019) Classification of North Africa for use as an extended pseudo invariant calibration sites (EPICS) for radiometric calibration and stability monitoring of optical satellite sensors. Remote Sens 11:875

Song W, Deng X (2017) Land-use/land-cover change and ecosystem service provision in China. Sci Total Environ 576:705-719

Sun S, Sun G, Caldwell P, McNulty S, Cohen E, Xiao J, Zhang Y (2015) Drought impacts on ecosystem functions of the U.S. National Forests and Grasslands: Part II assessment results and management implications. For Ecol Manage 353:269-279

Susani J, Zobeyri M, Feghhi J (2010) application of aerial photos and satelitte images in viewing Zagros Forest cover (case study: forests of Kaka Reza area of Lorestan province). IJFPR 17(2):237-249

Tahiru AA, Doke DA, Baatuuwie BN (2020) Effect of land use and land cover changes on water quality in the Nawuni Catchment of the White Volta Basin, Northern Region. Ghana. Appl Water Sci 10:198. https://doi.org/10.1007/s13201-020-01272-6

Torabi Haghighi A, Darabi H, Shahedi K et al (2020) A scenario-based approach for assessing the hydrological impacts of land use and climate change in the Marboreh Watershed, Iran. Environ Model Assess 25:41-57. https://doi.org/10.1007/s10666-019-09665-x

Vesely FM, Paleari L, Movedi E et al (2019) Quantifying uncertainty due to stochastic weather generators in climate change impact studies. Sci Rep 9:9258. https://doi.org/10.1038/ s41598-019-45745-4

Yang J, Xie B, Zhang D et al (2021) Climate and land use change impacts on water yield ecosystem service in the Yellow River Basin, China. Environ Earth Sci 80:72. https://doi.org/10.1007/ s12665-020-09277-9

Yin G, Wang X, Zhang X, Fu Y, Hao F, Hu Q (2020) InVEST modelbased estimation of water yield in North China and its sensitivities to climate variables. Water 12:1692. https://doi.org/10.3390/ w12061692

Zhao YR, Zhou JJ, Lei L, Xiang J, Huang MH, Feng W, Zhu GF, Wei W, Wang JA (2019) Identification of water yield driving factors in the upper reaches of Shiyang River based on InVEST model. Chin J Ecol 38(12):3789-3799. https://doi.org/10.13292/j.10004890.201912.017

Publisher's Note Springer Nature remains neutral with regard to jurisdictional claims in published maps and institutional affiliations. 